\title{
The Central Modernist Question
}

\author{
Programmatic Goals and the Broader Intellectual Context of the \\ Journal Život
}

Tadija Milikić*

\begin{abstract}
Summary
This paper presents an insight into the programmatic goals and broader intellectual context of the journal Život ("Life") which was published continuously for a quarter of a century until the end of World War II (1919-1944) and which, after twenty-six years, was reissued in 1971 under a new name, namely, Obnovljeni Život. In the paper there is a concise presentation of the goals of the journal based on a brief programmatic text titled "What We Want" which can be found at the very end of the first volume. Then there is given an insight into the realisation of the same goals based on selected articles and essays from the first year of publication of the journal with its ten issues. Finally, in the central and most important sections of the paper, an insight is given into the broader movements of thought of the human spirit such as nominalism, the empirical sciences, neo-scholastics, Thomism and modernism in the historical context of which the journal Život appears and acts as a creative expression of the intelligence of the faithful and as a recognisable sign of a time in which one lived in the light and in the shadow of the central modernist question.
\end{abstract}

Key words: Život, scientific journal, nominalism, empirical sciences, neoscholastics, neo-Thomism, modernism

\section{Introduction}

The Board of Editors of the journal Život presented its brief programmatic text under the title What We Want, which can be found at the very end of the first volume (Board of Editors, 1919). There the editors draw our attention primarily to the dechristianization process and the creation of a non-Christian mentality, which was first embraced by the intellectual and then by the broader classes. The causes for this state of affairs were identified by the Board as stemming from a great lack of understanding of the faith and of morality and from the spreading of erroneous principles, particularly materialistic principles. Their analysis was confirmed by the increasing estrangement

* Tadija Milikić, Ph.D., Faculty of Philosophy and Religious Studies, University of Zagreb. Address: Jordanovac 110, Zagreb, Croatia. E-mail: tmilikic@ffrz.hr 
of everyday human life from the perfect Christian ideal, which is not to be attained merely by keeping many and sundry commandments, but by imitating Jesus Christ. Having concluded thusly, the Board of Editors turned to the "Catholic secular intelligentsia" and took upon themselves the task to help, through their journal, in all things that it "can and must do in order to capture the interest of the Catholic lay person" and that have to do with faith and morals. The Board declared that it would do this either directly by putting forward the magisterial teaching of the Church and individual theological disciplines, or indirectly by addressing various philosophical, literary, sociological and similar issues which may have anything at all to do with faith and morals; also, that they would put a focus on "fostering internal supernatural life" not only by means of original articles, but also with the translations of the fine spiritual works of great Catholic nations (Board of Editors, 1919).

Although the journal was launched in the wake of WWI, and although it contains articles at least indirectly linked to the horrors of war, they always reflect the perspective of the aforementioned programmatic goals of the journal. For instance, in his analysis of the atrocities of war in which "human culture demonstrated itself to be an empty husk of grain" and "science degraded itself to the post of a servant to man's forceful passions" Grgur Galović points to man's internal life as their deepest cause. Aside from reminding us of the first pages of Holy Scripture where the biblical author endeavours to provide an answer to the question of evil in the world, Galovićs moral-theological analysis of the cause of the atrocities of war anticipates the social teachings of Pope John Paul II on social sin as well as his theological analysis of contemporary issues. For example, the aforementioned Pope very clearly states that social sin is the product, the accumulation and concentration of multiple personal sins (SRS 16) which are recognisable by their exclusive greed for profit and thirst for power "with the intention of imposing one's will upon others [...] at any price" (SRS 37). It should be stressed, however, that Galović does not speak of man's personal inner life only as a source of evil, but also as a source of human greatness. He believes that a great man is not great because he is a great artist, scientist, statesman or politician, but he is great simply because he is a man. Being a man and having dominion over the entire microcosm hidden in every man simply because he is a man, deems Galović, demands a far greater knowledge and skill than do the various fields of science and capabilities needed to govern the external world within one's family, society and nature (Galović, 1919).

In keeping with their programmatic goals and with the great theological intuition of St. Augustine that Christian life is impossible without God's help (Pinckaers, 2001, 151-155), the Board of Editors of the journal Život strived first and foremost to contribute to the edification and promotion of an authentic Christian life, that is, human life in all its fullness, which along with the human mind and human will necessarily requires also the light and power of God's Revelation (Galović, 1919, 77). Furthermore, the journal Život endeavoured to refute erroneous and unacceptable ideologies such as nationalism which can otherwise be a very convenient source of support for the design and implementation of an extremely cruel programme of human selfishness. The young student Ivan Merz 
also writes about precisely this kind of nationalism - a flawed and unacceptable ideology - as the worst invention of the West and refers to the reflections of Rabindranatha Tagore who perceives in European nationalism the "most powerful medium of self-deception ever invented by man” (Merz, 1919).

Along with short articles and small occasional contributions, such as the aforementioned articles by Grgur Galović and Ivan Merz, which comprise only one to two pages of text, each edition of the journal Život contains at least one scholarly paper, mainly five to seven pages long, sometimes nine pages, which comprises more than a third of the total number of pages, namely, twenty-four. At the time, these scholarly papers were distinguished by their high standards. They dealt mostly with scholarly and expert topics. They aroused the interest especially of the Catholic faithful among the intelligentsia, but they also attracted the attention of others who were at least intellectually curious, and who demonstrated an interest in titles such as Natural Scientists and Christianity, (Prirodoslovci i kršćanstvo written by Vanino in 1919), Christianity and Natural Scientists (Kršćanstvo i prirodoslovci written by Vanino, 1920a), Electrophysisists and Faith (Elektrofizičari $i$ vjera written by Zec in 1920), Mathematicians and Faith (Matematičari $i$ vjera by N. Buljan, 1920), The Position of Man in the Universe (Položaj čovjeka u svemiru by A. Buljan, 1920), Biblical Cosmogony in the Light of Science (Biblijska kozmogonija u svjetlu znanosti by Vlašić, 1920), Natural Sciences and World Outlook (Prirodoslovne znanosti i naziranje na svijet by Galović, 1920), Haeckel and Embriogenetic Transformism (Haeckel i embriogenski transformizam, Anon., 1920), Astronomers and Faith (Astronomi i vjera by Vanino, 1920b).

These papers were enhanced with ideas and theories which were spontaneously developed and clearly articulated. The effort of the author to be objective is evident as is also his diligence in documenting references. That which is conveyed in them emanates timeliness and novelty, while those who placed their signatures on the papers were mostly already well-known and acknowledged for their scientific and expert proficiency. ${ }^{1}$ As such, these scholarly papers were a recognisable feature of the journal Život. They accomplished, in the true sense of the word, the programmatic goals of the journal as was layed out at the beginning of this introduction. However, one would do well to stress that these goals cannot be understood correctly in all their demandingness and justifiability — as regards accessing the whole truth about the reality of Christian, or rather human life - unless they are placed into their original context which was determined by the movements of the human spirit of that time and which, utterly spontaneoulsy, became a precondition for the emergence of the journal Život and essentially determined its role in the historical circumstances at hand. This broader supportive intellectual context is evident in philosophical, theological and scientific currents of thought such as nominalism, the development of the empirical sciences, neoscholastics, neo-Thomism and modernism.

1 The first editor of the journal Život was elected corresponding member of the Yugoslav Academy of Sciences and Arts which fact supports our claims (Śišić, 1938). 


\section{Nominalism and its effect on the development of the empirical sciences}

The mental context within which the journal Život emerged and developed was, first and foremost, essentially determined by ideas stemming from nominalism which appeared as early as the 14th century and was especially associated with the thought and work of the English Franciscan William Occam (12871347). Through the next two centuries he was established as the main proponent of ideational movements of the human spirit. In actual fact, nominalism marks the beginning of the great turning point in the history of human thought. The medieval idea of order collapses. In his reflections man begins to drift away from the general and universal cosmic dimensions of reality and increasingly to focus on the individual, concrete empirical experience. Man begins to problematise his relationship with God and the world and to place himself at the centre of his thought. At the same time, he slowly paves the way toward systematic reflection which characterised the centuries-long period of modernity: the culture of exact observation of external facts gains impetus, and the epistemological and methodological critical consciousness is raised.

Gradually the empirical sciences began to gain dominance, and it became obvious and justifiable that the facts they proffered must not be ignored by metaphysics; indeed, that philosophy which had been dominant until then owed them its respect and its consistent and honest evaluation. In this context, a sound scepticism of philosophy and its grasp of integral reality grew increasingly. This process had an effect on the totality of human thought, including philosophicaltheological thought. Its effect is felt even today, particularly as we are required to become acquainted with, evaluate and respect the information coming from the empirical sciences. This means that philosophy and theology cannot speak properly, for example, about human nature and base their philosophising and theologising on it without keeping in mind, in an appropriate manner, the relevant findings of the empirical sciences. Therefore, a consciousness about the necessity for interdisciplinary dialogue with the empirical sciences was slowly evolving in philosophy and theology.

Unfortunately, during the 19th century the empirical sciences took on the dominant role in the scientific field to the extent that the concept of science began to be identified with the concept of empirical sciences, and the notion of truth was being reduced to the concept of scientific or experimental truth (Comte, 1989, 26). ${ }^{2}$

This new development effected a change in roles in the encounter between the humanistic and the empirical sciences. Those that fought for and forged their own scientific identity now negated an identity to those that formerly did the same to them. This encounter between the humanistic and natural sciences is still writing

2 "All competent thinkers agree with Bacon that there can be no real knowledge except that which rests upon observed facts" (Comte, 1989, 26). 
its own history. Many challenges lie ahead and in order to bring about a productive collaboration, not only openness to the integral truth is required, but also an appropriate grasp of it through an increasingly better understanding of the possibilities and limits of one's knowledge. Understandably, this encounter takes place in a different dynamic depending upon various linguistic, cultural and national frameworks. In some environments this encounter is almost imperceptible, while in others it is on a very high level. The latter particularly applies to those fields in which an interdisciplinary scientific dialogue can draw on the university, that is, on highly developed sciences, both the natural and humanistic. As it is today, so it was at the time of the emergence and evolvement of the journal Život.

\section{Neo-scholastics and neo-Thomism}

A person well-versed in neo-scholastics is apprehensive about making rash and generalised statements which do not take into account its diverseness, complexity, greatness and richness. It is true that neo-scholastics presents also movements of thought which were the object of a critical reaction by the Council's renewal efforts.

However, neo-scholastics has the full right to be included also in the pre-conciliar renewal efforts which made a crucial impact on the preparation, development and directives of the theology of the Second Vatican Council. Neo-scholastics is all of this. It may be understood as an important medium for Church teachings both in the battle against modernism within the Catholic Church, as also in the battle against unacceptable currents of thought such as positivism, historicism, relativism, biologism and materialism. Unfortunately, in its assumed, or better said, defensive role, neo-scholastics not only shielded Catholic thought, but also hindered its spontaneous, open and constructive confrontation with scientific movements of its time. Fortunately, neo-scholastics may be understood also - and justifiably and groundedly so - as the aspiration of the faithful among the intelligentsia - to the degree of its abilities - to always respond in new ways to the ever-new and unrepeatable intellectual challenge of doing historical research and making a concrete expression of one's faith in the new categories and ideas that are available in one's time (fides quaerens intellectum). Pope Leo XIII (1810-1903), who was very knowledgeable in regard to cultural, political and social circumstances and predicaments of the world in which he lived, recognised this challenge. Precisely for this reason does this Pope, with his encyclical Aeterni Patris (1879) in which he invites us to return to the sound teachings of St. Thomas Aquinas, give a strong impetus to the renewal efforts of Christian thought. As a consequence of this impetus, there emerged a renewal movement called neo-Thomism, the goal of which was a return to the original teachings of St. Thomas Aquinas (AP; Demmer, 2000, 37-40). This was a strong and creative renewal movement which, as regards its amibitions and achievements, proved to be a great deal more than a mere return to former, medieval Christian thought. 
Since the aforementioned latter detail about neo-scholastics is far more essential for a proper understanding of the appearance and evolvement of the journal Život, let us devote just a little more space to it by pointing out some philosophers and theologians who accepted not only the invitation of Pope Leo XIII, but also the challenge of contemporary movements of thought, and endeavoured, faithfully and creatively, to integrate them into the original Christian thought and authentically theological categories of Aquinas's teachings, in particular. For instance, in 1922 Cardinal Desiré Mercier (1851-1926) founded the Institute of Thomist Philosophy at the Catholic University in Louvain at which Miroslav Vanino, the first editor of the journal Život, studied only a few years prior to this time. Similarly, the Jesuit Joseph Maréchal (1878-1944) who was very knowledgeable in both scholastic and contemporary thought, succeeded in establishing a dialogue between Thomas's and Kant's thought, which resulted in a new Thomism, known as transcendental Thomism. It is interesting to note that only with the help of this new Thomism did Catholic philosophical-theological thought succeed, not only in overcoming its classic repugnance toward Kant's philosophy of critiques, but also - by drawing precisely upon it - managed effectively to better understand and more fully expose the fundamental ideas of Thomas's authentic metaphysics, which were neglected and forgotten in the Thomist tradition, and which draw on the importance and role of the human subject: ideas which are very close to the ideas of the contemporary period, and which were greatly influenced by Kant's thought. The same holds for Theodor Steinbüchel (1888-1949) who enriched scholastic philosophy and theology with elements of contemporary philosophy. Along with Kant's philosophy of critique, we have also existentialism, personalism, philosophy of values and phenomenology.

To the list of eminent Catholic philosophers and theologians of the neo-scholastic or rather neo-Thomist period, such as Bernard Lonergan (1904-1984), Joseph de Finance (1904-2000), Emmerich Coreth (1919-2006), Johannes Baptist Lotz (1903-1992) and Karl Rahner (1904-1984), must also be added several theologians who by means of their theological writings built themselves into the renewal endeavours of their time, such that they strived for an open and constructive dialogue of their authentic and powerful Christian thought with new congitive insights and questions. These demonstrate not only a departure from unacceptable theological essentialism, objectivism, legalism and minimalism, but also a better understanding and consistently more appropriate interpretation of the richness of our theological legacy in compliance with the intellectual categories of the contemporary moment. For example, the most prominent representative of German neo-Thomism, Carl Joseph Mausbach (1861-1931), strives to theologise theology, that is, to find at its core the central object and endeavours to focus on it unceasingly in his reflections. His works give us a glimpse of the personalistic and historical categories which point to the demand for a deeper connection between Christian teaching and Christian life, that is, human life.

At that time in French-speaking countries, where a growing, almost galloping, secularisation could especially be sensed, Dominican theologians such 
as Gustave Thils (1909-2000), Marie-Dominique Chenu (1895-1990), Yves Congar (1904-1995) Gontran-Réginald Garrigou-Lagrange (1877-1964) i Antonin-Gilbert Sertillanges (1863-1948) stood firmly on the solid ground of both Thomas's medieval and also of contemporary thought and thus brought about a strong development in the field of theology, which was the first to be denounced on account of modernism, but was later rehabilitated. These theologians, who at that time were leaders in their field, developed a theology now known as the new theology. In it they elaborated the theology of temporal realities and the theology of labour. In their theological writings they strived to conjoin theology and spirituality, or rather theoretical universal teaching and practical real life. At the core of their theological research lies the problem of historicity. The results of their scientific research are not in accord with disjunction but rather conjunction. For instance, they do not separate, but rather connect realities such as the eternal and the temporal, the universal and individual, the supernatural and natural, the Church and the world. In this respect they struggle with tendencies within the Church which, in criticising the world, in fact, isolate the Church from the world. Similarly, we would do well to stress that theologians did not apply their historical method only in reading Aquinas's works, but also in gaining an understanding of the immutable eternal truths of the faith (dogmas) which occur and are fulfilled in history and are therefore essentially characterised by this self-same history. These theologians contributed in a faithful and creative way to the creation of new, more comprehensive and appropriate categories which are an expression of the contemporary Christian faithful among the intelligentsia.

This list must also include Jacques Maritain (1882-1973), one of the greatest Catholic thinkers of the 20th century, who with his theology influenced the official theology of the Magisterium of Pope John XXIII and Pope Paul VI. His ideas about integral humanism, the horizon of Christian intentionality and core commitment made a profound effect on the general development of 20th century theology (Demmer, 2000, 11-12). Similarly, as regards the open and constructive encounter between Christian thought and contemporary science, two French Jesuits stand out, namely, Pierre Rousselot (1878-1915) and Henri de Lubac (1896-1991), the latter being considered by some to be one of the most influential theologians of the 20th century. His theological research produced abundant results which played a key role in the development of a theology which was first condemned for modernism but later rehabilitated and recognised as the theology of the Second Vatican Council. For example, in researching the history of theological anthropology, particularly in his works Surnaturel: Études historiques (1946), Histoire et esprit: l'intelligence de l'Écriture d'apres Origene (1950) i Le Mystere du surnaturel (1965), Lubac noticed certain deformations of the Christian notion of man, while the most important cause of these deformations was pinpointed as being the erroneously understood and interpreted relationship between the natural and the supernatural

In his reconstruction of theological anthropology he draws particularly on the Calcedonian Council, which speaks of unity, though not of an intermingling; 
rather of diversity, though not of the separation of the natural from the supernatural (Denzinger i Hünermann, 2002, 86-87). In light of the aforementioned teaching on unity and diversity of the human and divine nature of Jesus Christ, Lubac finds his inspiration for a better theological understanding of human nature itself. He claims that man by his very nature is directed toward the supernatural, that which is realised in fullness in Jesus Christ. In this sense, the profound natural human directedness to the immeasurable and infinite is not something coincidental and done in passing, says Lubac, but rather something without which man in his nature is ultimately non-understandable and ungraspable, something without which man cannot find his true centre and his deepest purpose. As a theologian, Lubac is aware that speech about man is incomplete and essentially lacking if it does not include speech about God Who is closer to him than he is to himself, Who reveals Himself and Who reveals to man his true human nature in Jesus Christ. According to Lubac, the supernatural is not just an external appendage to a better understanding of man, his nature and his activity, but rather an integral and constituent part of human identity and a most profound and indestructible foundation for true human, that is, Christian living. It would be wrong to conclude that Lubac's speech about the relationship between the natural and the supernatural eliminates the need for natural, rational argumentation. On the contrary, on the one hand he demands an openness of rational argumentation in regard to that which surpasses it, while on the other hand he confirms the ability of the same argumentation to accept and inform us of his perception of the supernatural in a proper rational manner. With this brief insight into Lubac's thought, the problem of modernism has already been introduced. It characterised the immediate intellectual context in which the journal Život appeared and evolved (Lubac, 1965, 79-103, esp. 81).

\section{Modernism}

Modernism is one of the most complex and most sensitive periods in the history of the Catholic Church. It encompasses in particular the second half of the 19 th and the first half of the 20th century. However, one would do well to keep in mind that modernism took place within the much needed, very demanding and ever-new dialogue between theology and science, faith and reason, the Gospels and culture, the Church and the world. This is a dialogue which began in the Apostolic period, continued through the era of the Church Fathers and the scholastics and kept on developing through the centuries-long New Era up until the contemporary moment, which endeavours to make its contribution to a better understanding and achievement of a productive encounter between faith and reason. In some historical periods this encounter was at the peak of its potential and an inspiration for future times. Unfortunately, in some periods such as modernism, the same encounter was merely a testimony to failed attempts, which demonstrated ignorance of one's identity and a lack of respect for epistemological differences and methodological limitations. All of this had a negative effect on true dialogue and so condemned to failure the achievement of a constructive 
and productive encounter between theology and philosophy, supernatural and natural wisdom, the Church and the world.

One may speak of various forms of Catholic modernism, such as radical and moderate, speculative and practical, philosophical and theological. Proponents of modernism present themselves as a reformist movement of the religious sciences, while in its formal documents the Magisterium calls modernism "the synthesis of all heresies" (PDG 39). In this respect, many prominent authors, such as the Jesuits Enrico Rosa i Giovanni Sale (Sale, 2007), consider that modernism above all refers to the radical and theoretic modernism which emerged firstly in the field of Catholic philosophy, then theology as well in all its disciplines. Reformist movement thought is very deeply rooted in the nominalist ideas of the 14th century, and it finds its immediate intellectual premise in the ideas of positivism which established itself as the dominant philosophy of the 19th century and which, as such, had a profound effect on the development of all other scientific disciplines (Comte, 1989, 26). Modernism first appeared in Western Europe, in particular France, Belgium, Germany and Italy where Catholic philosophy and theology remained in the academic haute monde of the other scientific disciplines and in this respect were under their strong influence.

At that time, the Catholic faithful among the intelligentsia noted firstly within university and academic circles, then on the level of the general culture of their time, a great gap between theology and science, or rather, faith and reason. Though this was an issue of making a justified effort to reconcile faith and reason in an appropriate way as the two salient sources of human knowledge, nevertheless one must acknowledge that the proponents of modernism did not succeed in this, and that their recommended solutions, rather than establishing a constructive and fruitful dialogue, unfortunately gave rise to a grave threat to the identity and integrity of their own faith. This threat was noted by the Magisterium which reacted justifiably more than once in the official documents of the Church. The most powerful intervention was evident in the encyclical Pascendi Dominici gregis in 1907, which analyses and interprets modernist attitudes systematically and then proceeds to point out their causes as well as the appropriate means for solving and overcoming them. The author shall not discuss the stormy and dramatic history behind this document of the Church, rather he wishes to remind briefly of its philosophical-theological teaching, which had a profound effect on the programmatic goals of the journal Život and consistently affected the appearance of this teaching in scientific periodicals of the Church in this part of the world.

The central issue in regard to modernism is perceived by Pascendi Dominici gregis to be on the level of philosophy, in so-called "philosophical modernism" which draws on positivist hypotheses such as subjectivism, immanentism, scepticism, agnosticism, relativism and atheism. In accordance with the foregoing, as also with Kant's philosophy of critique, this type of modernism negates the capability of reason to grasp true, secure and objective knowledge, whether it be natural or supernatural knowledge (PDG 9). This modernist epistemology may be found in the philosophical groundwork of theological disciplines. In this case, 
we are no longer dealing only with philosophical but rather with theological modernism, which is evident in its immanentism and symbolism (PDG 19-20). For example, modernist biblical exegesis deprives faith of its objectivity, rationality and integrity, and reduces it to subjective, vague and incoherent religious sentiment, thus setting it against science which alone proffers real, true, secure and verifiable claims. Similarly, modernist dogmatics identifies its grasp of Revelation with religious sentiment and human consciousness and considers Christianity, as also all other religions, a mere product of human nature; furthermore, it deprives dogmatic truths of their immutable revealed content (Sale 2007). This and many of the other solutions which modernists have come upon in their effort to modernise the Catholic faith and to bring it into harmony with the new epistemological demands of their time, give a quick insight into their incompatibility with the Catholic faith and its fundamental truths, such as the identity and integrity of faith, the supernatural character of Revelation and the revealed and immutable content of dogmatic truths.

\section{Conclusion}

At the end of this brief insight into the programmatic goals of the journal Život and the broader intellectual context in which the journal emerged and thrived in the first half of the 20th century, the author would like to underline the concluding thought that the journal Život was, in the true sense of the word, a recognisable sign of its time within the particular Church. That which was happening at this time on the level of Catholic philosophical and theological thought movements within the universal Church, especially in the countries of Western Europe, such as France, Belgium, Germany and Italy, also was happening in the small particular Church of the Croats, to the extent that historical circumstances and opportunities allowed. The foregoing underscored conclusion is substantiated perfectly clearly by a very interesting parallel which exists between the programmatic goals of the journal Život in 1919 on the one hand, and, on the other hand, the programmatic goals which may be discerned in the encyclical Pascendi Dominici gregis written by Pope Pius X twelve years earlier.

Here are a few very important parallels which may be drawn between the journal Život and the encyclical Pacendi Dominici gregis. On the level of analysis of the state within the Catholic Church, the journal Život points out dechristianization processes which first embraced the intellectual and then the broader classes. The encyclical Pascendi Dominici gregis speaks in much the same way when pointing out modernist misconceptions of Catholic philosophy and theology and warns of the danger that they may spill over from the theoretical level onto the practical level. Similarly, both identify the causes for the alarming new developments in the Church. The journal does this on the particular level and the encyclical on the level of the universal Church. Namely, the journal Život detects the causes for the dechristianization process in the lack of understanding of the faith and morality and in the spreading of false principles, particularly 
materialistic principles, while the encyclical Pascendi Dominici gregis reveals the root of modernist ideas to be in agnosticism and immanentism, which are characteristic of the positivist philosophy. Finally, there is a parallel to be drawn, just as on the level of the goals of the journal and the encyclical, so too on the level of their interlocutors. For example, the journal Život addresses the Catholic intelligentsia and makes the commitment to support it by presenting and promoting magisterial teaching and implicating false teachings, which in a similar way the encylical Pascendi Dominici gregis also does in addressing the entire Church in its great endeavour to defend fundamental Christian truths and disclose concealed modernist misconceptions.

Having noted that there exists a parallel between what the journal Život does on a particular, and the encyclical Pascendi Dominici gregis does on the universal level of the Church, the author would like to point out that — based on an insight into the programmatic goals of the journal and the broader intellectual context of its appearance and evolvement — one may conclude that the journal Život is characterised essentially by an intelligence of the faithful, that is, reason enlightened by faith, which means that the journal Život deals directly with theological and indirectly with philosophical and other scientific disciplines.

\section{Bibliography:}

AP. Aeterni Patris. (August 4, 1879.) Leo XIII., Aeterni Patris: Jedinorođeni Sin Vječnoga Oca. In: Jacques Maritain, Životno djelo sv. Tome Akvinskog (pp 177-202). Zagreb: Zadruga Eneagram, 2011.

Buljan, Antun (1920). Položaj čovjeka u svemiru. Život, 1(7), 161-169. [Signed by: Dr. A. Buljan. Sarajevo.]

Buljan, Nikola (1920). Matematičari i vjera. Život, 1(6), 121-127.

Comte, Auguste (1989). Kurs pozitivne filozofije. Nikšić: Štampa Kultura.

Demmer, Klaus (2000). Shaping the Moral Life: An Approach to Moral Theology. Washington: Georgetown University Press.

Denzinger, Heinrich; Hünermann, Peter (ed.) (2002). Zbirka sažetaka, vjerovanja, definicija i izjava o vjeri i ćudoređu. Đakovo: Karitativni fond UPT Đakovo.

Galović, Grgur (1919). Najpreča zadaća. Život, 1(4), 75-77. (signed by: G. Galović. Đakovo.)

Galović, Grgur (1920). Prirodoslovne znanosti i naziranje na svijet. Život, 1(8), 199-204. [Signed by: G. Galović. Đakovo.]

Kujundžić, Joanes Evangelista (1920). Haeckel i embriogenski transformizam. Život, 1(9), 209-212. [Signed by: Po predavanju A. Acloque-a priredio JEK.]

Lubac, Henri de (1946). Surnaturel: Études historiques. Paris: Éditions Montaigne.

Lubac, Henri de (1950). Histoire et esprit: L'intelligence de l'Écriture d'après Origène. Paris: Éditions Montaigne.

Lubac, Henri de (1965). Le Mystere du surnaturel. Paris: Éditions Montaigne.

Merz, Ivan (1919). Rabindranath Tagare o Evropi. Život, 1(4), 85-86.

PDG. Pascendi Dominici gregis. (September 8, 1907.) Pio X., Pascendi Dominici gregis. U: Papinsko vijeće za kulturu (ed.), Vjera i kultura: Antologija tekstova papinskog učiteljstva od Lava XIII. do Ivana Pavla II. (str. 55-88). Zagreb: Kršćanska sadašnjost, 2010.

Pinckaers, Servais (2001). The Sources of Christian Ethics. Edinburgh: The Catholic University of America Press. 
Sale, Govanni (2007). A un secolo dall'enciclica contro il modernismo: Il contributo della "Civiltà Cattolica" alla redazione della "Pascendi". Civiltà Cattolica, 3775, 9-19.

SRS. Sollicitudo rei socialis. (Decemer 30, 1987.) John Paul II., Sollicitudo rei socialis: Socijalna skrb. In: Marijan Valković (ed.), Socijalni dokumenti Crkve: Sto godina katoličkoga socijalnog nauka (pp 573-624). Zagreb: Kršćanska sadašnjost, 1991.

Šišić, Ferdo (1938). Dr. Miroslav Vanino D. I. In: Ljetopis Jugoslavenske akademije znanosti i umjetnosti za godinu 1936/37 (pp 106-107). Zagreb: Nadbiskupska tiskara.

Uredništvo (1919). Što hoćemo. Život, 1(1), 21-22.

Vanino, Miroslav (1919). Prirodoslovci i kršćanstvo. Život, 1(1), 1-5.

Vanino, Miroslav (1920a). Kršćanstvo i prirodoslovci. Život, 1(4), 70-74.

Vanino, Miroslav (1920b). Astronomi i vjera. Život, 1(10), 242-249.

Vlašić, Petar (1920). Biblijska kozmogonija u svjetlu znanosti. Život, 1(8), 185-191.

Zec, Franjo (1920). Elektrofizičari i vjera. Život, 1(5), 89-94.

Središnje modernističko pitanje

Programatski ciljevi i širi intelektualni kontekst časopisa Život Tadija Milikić*

Summary

Ovaj rad donosi uvid u programatske ciljeve i širi intelektualni kontekst časopisa Život koji je izlazio kroz četvrt stoljeća sve do konca Drugoga svjetskog rata (1919.1944.) i koji će nakon dvadesetšest godina 1971. godine biti ponovno pokrenut pod novim imenom Obnovljeni Život. U njemu se najprije sažeto predstavljaju ciljevi časopisa na temelju kratkog programatskog teksta »Śto hoćemo. koji se nalazi pri samom kraju prvog sveščića časopisa. Zatim se daje uvid u ostvarivanje istih ciljeva na temelju izabranih dvovrsnih radova iz prvog godišta časopisa s njegovih 10 sveščića. I konačno, u središnjim i najvažnijim dijelovima rada daje se uvid u šira misaona kretanja ljudskog duha kao što su nominalizam, empirijske znanosti, neoskolastika, tomizam i modernizam, unutar kojih se pojavljuje i djeluje časopis Život kao kreativni izraz vjerničke inteligencije $i$ kao raspoznatljivi znak svog vremena, u kojem se živjelo u svjetlu i sjeni središnjeg modernističkog pitanja. Ono što se u tom razdoblju događalo na razini misaonih kretanja katoličke filozofije i teologije unutar univerzalne Katoličke crkve osobito u zemljama Zapadne Europe kao što su Francuska, Belgija, Njemačka i Italija, to isto se zbivalo na području malene partikularne Crkve u Hrvata u skladu s njenim povijesnim prilikama i mogućnostima. Ovu tvrdnju sasvim jasno potkrepljuje i vrlo zanimljiva paralela koja postoji između programatskih ciljeva časopisa Život iz 1919. godine s jedne strane, $i$ s druge strane programatskih ciljeva koji se daju razaznati u enciklici Pascendi Dominici gregis koju je napisao papa Pio X. dvanaest godina ranije (1907.).

Ključne riječi: Život; znanstveni časopis; nominalizam; empirijske znanosti; neoskolastika; neotomizam; modernizam

* Dr. sc. Tadija Milikić, Fakultet filozofije i religijskih znanosti Sveučilišta u Zagrebu. Adresa: Jordanovac 110, Zagreb, Hrvatska. E-adresa: tmilikic@ffrz.hr 